\title{
Oral health knowledge, attitude and practice (KAP) among prison inmates of Ambala District, Haryana (India)
}

\author{
Rajeshwar Digra*, Nidhi Gupta, Vikram Arora and Preety Gupta \\ Department of Public Health Dentistry, Swami Devi Dyal Hospital and Dental College, Panchkula, Haryana, India
}

\begin{abstract}
Aim: The study was to assess the oral health knowledge, attitude and practice among prison inmates of Ambala district (Haryana) India.

Materials and method: It was a cross sectional study conducted on 570 prisoners after meeting the eligibility criteria. A 23 item closed ended structured questionnaire was used to assess the oral health related knowledge, attitude and practice among prison inmates.

Results: the results show that oral health knowledge was poor among prisoner as 51\% of the subjects did not know about the meaning of gum bleeding and $83 \%$ of subjects have no knowledge of dental plaque. Knowledge about injurious effects tobacco was better. Prisoner shows their negative attitude towards dental treatment as $45.6 \%$ of the subjects think, it is necessary to visit a dentist and $62.24 \%$ of the subjects had never visit to a dental clinic even before imprisonment. $38.66 \%$ of the subjects had their last visit for more than five year ago. Tooth extraction (27.4\%) was the most common cause of last visit. Practice among prisoner reveals, $58 \%$ of the subjects do brush their teeth at least once a day and most of the subjects $90 \%$ use toothbrush and paste for cleaning their teeth. Most of the subjects (79\%) brush their teeth in morning and 59\% perform brushing for more than 2 minute.
\end{abstract}

Conclusion: Oral health education should be imparted to the prisoner time to time and De-addiction clinics or programs should be establish in the prisons.

\section{Introduction}

Health is a fundamental right of every individual and oral health is an integral part of general health [1]. National and international health care delivery systems have finally come to the conclusion of concentrating on primary and secondary level of health care to lessen the burden of expenditure for the state and to reduce the burden of ill-health on the community $[1,2]$. Access is one of the main barriers of health care delivery system which is needed to overcome by primary health care [2].

Population is not unique but dynamic. Each population group needs different approach for health care. One of the strategies in public health is to identify unique population groups, study their health problems and explore methods for health care. Prisoners make a special group of population as they are different from other people in context of their "freedom of movement [1-3]. Prisoners are psychologically, socially and morally affected group and are usually from low socioeconomic background. Such socio demographic factors are closely associated with poor health status and when they are admitted to correctional institutions (prisons), they are deprived of their liberty for a period that may be long or of uncertain period. Deprivation of liberty inevitably involves deprivation of choices taken for granted in the outside of the community. They can no longer freely decide where to live, with whom to associate and how to fill their time and must submit to discipline imposed by other. Communication with family and friend is limited and is often without privacy $[1,2]$.

Many prisoners entered the prison with poor oral health requiring emergency treatment this may be due to lack of knowledge about good oral health practices. Substance misuse contributes to high levels of tooth decay and gingival disease. Tobacco use increases the prevalence and severity of periodontal diseases and by for the greater risk of oral cancer [4].

The lack of knowledge about good oral health and negative attitude might be another cause of poor health. There is no such literature available which reveal the knowledge, attitude and practices among the prison inmates about oral health so that comparison can be done in order to find out differences between general population and prisoners. Therefore, the present study is being taken to reveal their knowledge, attitude and practices about oral health.

\section{Materials and method}

The study was conducted to assess the oral health knowledge, attitude and practice among 570 inmates of Ambala district (Haryana) India.

Prior to the onset of the study, the ethical clearance and permission was obtained from the concerned authorities to carry out the study.

The eligibility criteria includes those subjects who were willing to participate The entire prisoners were included in the study that was willing to participate and hard Core Prisoner, those were not allowed to get out of cell for more than one hour per day were excluded.

A 23 item closed ended structured questionnaire was used to assess

Correspondence to: Rajeshwar Digra, Department of Public Health Dentistry, Swami Devi Dyal Hospital and Dental College, Golepura, Barwala, Distt. Panchkula-134118, Haryana, India; E-mail:

Keywords: knowledge, attitude, oral heath, prison inmates, smoking

Received: June 01, 2015; Accepted: July 17, 2015; Published: July 22, 2015 
the oral health related knowledge, attitude and practice among prison inmates. The questionnaire was reviewed by experts to ensure the content validity and then translated to the local language (Hindi) for better understanding of the subjects. Pilot study was done to determine the reliability of the survey questions in the present scenario. After the pilot study, necessary changes were done in the questionnaire.

Descriptive statistics were obtained and mean, standard deviation and frequency distribution were calculated. Data was analyzed using the statistical package for social science 17.0 (SPSS 17.0).

\section{Results}

The demographic details of the subject shows mean age was 35.26 years with a standard deviation of 12.29 years. The minimum subject age was 18 years while the maximum was 88 years.

Table 1 shows the distribution of study subjects according to gender, educational qualification and occupation prior to imprisonment. A total of 52 (9.12\%) females and 518 (90.9\%) males were explored in the study. Distribution of education level amongst the prisoners with maximum subjects (26\%) being illiterate followed by $20.6 \%$ with high school education. $10 \%$ of the study subjects having graduation degree with $7.2 \%$ and $2.8 \%$ of the subjects having graduation and post graduation degree respectively. Distribution of the subjects according to the occupation before imprisonment, on interview, it was revealed that maximum prison subjects examined belonged to class $\mathrm{V}$ clerical, shopkeeper, former partly (30.05\%) before entry into prison. $14.2 \%$ of the subjects belong to class 1 unemployed. Although $15.38 \%$ of the subjects were belongs to the semiprofessional class.

Table 2 shows the knowledge of study subjects regarding oral health. Most of the subjects (95.4\%) agreed with the fact that oral health is a part of general health. $47 \%$ of the subjects were aware about the dental caries and $80 \%$ of the subjects believes that brushing of teeth can prevent dental decay. However, $51 \%$ of the subjects were unaware about the meaning of gum bleeding, whereas $40.8 \%$ of the subjects had some knowledge of it. Knowledge about, how to prevent from gum

Table 1. Distribution of study subjects according to Gender, educational qualification and Occupation prior to imprisonment.

\begin{tabular}{|l|c|c|}
\hline \multicolumn{2}{|c|}{ Gender } \\
\hline Males & Frequency & Percent (\%) \\
\hline Females & 518 & 90.9 \\
\hline & 52 & 9.1 \\
\hline Illiterate & $\mathbf{1 4 8}$ & $\mathbf{2 6 . 0}$ \\
\hline Primary school & 70 & 12.2 \\
\hline Middle school & 105 & 18.5 \\
\hline High school & 117 & 20.6 \\
\hline Intermediate & 73 & 12.9 \\
\hline Degree & 45 & 7.9 \\
\hline Postgraduate & 12 & 2.1 \\
\hline & Occupation & 13.34 \\
\hline Unemployed & 76 & 2.9 \\
\hline Unskilled & 17 & 6.03 \\
\hline Semi Skilled & 34 & 18.1 \\
\hline Skilled worker & 103 & $\mathbf{3 0 . 0 5}$ \\
\hline Clerical, Shopkeeper, Former & $\mathbf{1 7 1}$ & 15.38 \\
\hline Semi-Professional & 88 & 14.2 \\
\hline Professional & 81 & 100.0 \\
\hline Total & 570 & \\
\hline & & \\
\hline
\end{tabular}

Table 2. Distribution of knowledge Score among prison inmates regarding oral health.

\begin{tabular}{|c|c|c|}
\hline & Frequency & Percent (\%) \\
\hline $\begin{array}{l}\text { 1. Do you know dental health is as important as } \\
\text { general health? } \\
\text { a) yes } \\
\text { b) No }\end{array}$ & $\begin{array}{c}544 \\
26\end{array}$ & $\begin{array}{c}95.4 \\
4.6\end{array}$ \\
\hline $\begin{array}{l}\text { 2. Do you know about dental caries? } \\
\text { a) yes } \\
\text { b) no }\end{array}$ & $\begin{array}{l}268 \\
302\end{array}$ & $\begin{array}{l}47.01 \\
52.99\end{array}$ \\
\hline $\begin{array}{l}\text { 3. Brushing of teeth can prevent dental decay? } \\
\text { a) yes } \\
\text { b) no }\end{array}$ & $\begin{array}{l}458 \\
112\end{array}$ & $\begin{array}{c}80.36 \\
19.7\end{array}$ \\
\hline $\begin{array}{l}\text { 4. What does gum bleeding mean? } \\
\text { 1. Healthy gum. } \\
\text { 2. Swollen gum. } \\
\text { 3. Gum recession. . } \\
\text { 4. I do not know. }\end{array}$ & $\begin{array}{c}21 \\
233 \\
24 \\
292\end{array}$ & $\begin{array}{c}3.6 \\
40.9 \\
4.2 \\
51.3\end{array}$ \\
\hline $\begin{array}{l}\text { 5. How do you protect yourself from gum bleeding? } \\
\text { 1. Using toothbrush and paste } \\
\text { 2. Using soft food. } \\
\text { 3. Regular visit to dentist. } \\
\text { 4. I do not know. }\end{array}$ & $\begin{array}{c}448 \\
34 \\
176 \\
616\end{array}$ & $\begin{array}{c}35.2 \\
2.7 \\
13.8 \\
48.4\end{array}$ \\
\hline $\begin{array}{l}\text { 6. What does plaque mean? } \\
\text { 1. Soft debris on the teeth. } \\
\text { 2. Staining of the teeth. } \\
\text { 3. Hard debris on the teeth. } \\
\text { 4. I do not know. }\end{array}$ & $\begin{array}{c}47 \\
31 \\
15 \\
477\end{array}$ & $\begin{array}{c}8.3 \\
5.4 \\
2.7 \\
83.6\end{array}$ \\
\hline $\begin{array}{l}\text { 7. What does dental plaque lead to? } \\
\text { 1. Swelling of the gum. } \\
\text { 2. Staining of the teeth. } \\
\text { 3. Dental caries. } \\
\text { 4. I do not know }\end{array}$ & $\begin{array}{c}62 \\
17 \\
17 \\
474\end{array}$ & $\begin{array}{c}10.8 \\
3.0 \\
3.0 \\
83.2\end{array}$ \\
\hline $\begin{array}{l}\text { 8. Do you know smoking is injurious to health? } \\
\text { a) yes } \\
\text { b) No }\end{array}$ & $\begin{array}{c}495 \\
75\end{array}$ & $\begin{array}{l}86.9 \\
13.1\end{array}$ \\
\hline $\begin{array}{l}\text { 9. Do you know chewing tobacco can cause oral } \\
\text { Cancer? } \\
\text { a) yes } \\
\text { b) No }\end{array}$ & $\begin{array}{l}411 \\
159\end{array}$ & $\begin{array}{l}72.06 \\
27.94\end{array}$ \\
\hline
\end{tabular}

bleeding was poor, as $48 \%$ of the subject did not know about it. When the subjects were asked about dental plaque, $83 \%$ of subjects had no knowledge of it. Most of the subjects $(86.81 \%)$ were aware that smoking is injurious to health and $72.05 \%$ of subjects were aware about chewing tobacco can cause oral cancer.

Table 3 shows attitude of prison inmates regarding oral health. The attitude of the subjects regarding oral health was poor as only $45.6 \%$ of the subjects think that it is necessary to visit a dentist and $62.24 \%$ of the subjects had never visited a dental clinic even before imprisonment Out of those who had a dental visit before imprisonment, $38.66 \%$ of the subjects had their last visit for more than five year ago. Tooth extraction (27.4) was the most common cause of last visit. The most common reason given by the subjects $(60.7 \%)$ for their last visit to dental clinic was dental pain. However, $49 \%$ of the subjects were not afraid at all when they visited to a dentist for the first time. Those who were never visited to a dentist gave the most common reason (42\%) that there is no pain to go to the dentist.

Table 4 shows distribution of practice score among prison inmates regarding oral health. Practice about oral health among the subjects was satisfactory as $58 \%$ of the subjects do brush their teeth at least once a day and most of the subjects $90 \%$ use toothbrush and paste for cleaning their teeth. Most of the subjects (79\%) brush their teeth in morning and $59 \%$ perform brushing for more than 2 minutes. However, the tobacco use practice among inmates was high as $59.4 \%$ of subjects use tobacco in any form and smoking was the most common form of tobacco use. 
Table 3. Distribution of Attitudes scores regarding oral health among prison inmates.

\begin{tabular}{|c|c|c|}
\hline & Frequency & Percent (\%) \\
\hline $\begin{array}{l}\text { 1. Do you think it is necessary to visit a dentist? } \\
\text { a). Yes } \\
\text { b) no }\end{array}$ & $\begin{array}{l}260 \\
310\end{array}$ & $\begin{array}{l}45.6 \\
54.4\end{array}$ \\
\hline $\begin{array}{l}\text { 2. How often do you visit your dentist? } \\
\text { 1. Regularly every } 6-12 \text { months. } \\
\text { 2. Occasionally. } \\
\text { 3. When I have dental pain. } \\
\text { 4. I never visited a dentist. }\end{array}$ & $\begin{array}{c}32 \\
92 \\
91 \\
355\end{array}$ & $\begin{array}{c}5.7 \\
16.1 \\
16.0 \\
62.2\end{array}$ \\
\hline $\begin{array}{l}\text { 3. Last time I visited a dentist was: } \\
\text { 1. Six months ago. } \\
\text { 2. Last } 6-12 \text { months. } \\
\text { 3. Last } 1-2 \text { years. } \\
\text { 4. Last } 2-5 \text { years. } \\
\text { 5. More than } 5 \text { years }\end{array}$ & $\begin{array}{l}44 \\
39 \\
20 \\
29 \\
83\end{array}$ & $\begin{array}{c}20.3 \\
18.2 \\
9.4 \\
13.4 \\
38.7\end{array}$ \\
\hline $\begin{array}{l}\text { 4.The treatment(s) I sought during my last visit to } \\
\text { the dentist was (were): } \\
\text { 1. Check my teeth. } \\
\text { 2. Take x-rays. } \\
\text { 3. Have scaling. } \\
\text { 4. Have fluoride on my teeth. } \\
\text { 5. Treat my gums. } \\
\text { 6. Have filling. } \\
\text { 7. Have crown/bridge. } \\
\text { 8. Have orthodontic treatment. } \\
\text { 9. Have tooth extraction. } \\
\text { 10. Others (specify)........... }\end{array}$ & $\begin{array}{c}46 \\
1 \\
44 \\
0 \\
8 \\
28 \\
21 \\
0 \\
59 \\
8\end{array}$ & $\begin{array}{c}21.2 \\
0.4 \\
20.41 \\
0 \\
3.9 \\
13.09 \\
9.9 \\
0 \\
27.4 \\
3.7\end{array}$ \\
\hline $\begin{array}{l}\text { 5. The reason for my last visit to the dentist was } \\
\text { 1. Dental pain. } \\
\text { 2. Family \& friend advice. } \\
\text { 3. A dentist advised me. } \\
\text { 4. Another reason (specify)........ }\end{array}$ & $\begin{array}{l}131 \\
20 \\
26 \\
38\end{array}$ & $\begin{array}{c}60.7 \\
9.5 \\
12.2 \\
17.6\end{array}$ \\
\hline $\begin{array}{l}\text { 6. When I first visited the dentist: } \\
\text { 1. I was scared and reluctant. } \\
\text { 2. Slightly afraid. } \\
\text { 3. Very slightly afraid. } \\
\text { 4. I was never afraid. }\end{array}$ & $\begin{array}{c}21 \\
40 \\
47 \\
107\end{array}$ & $\begin{array}{c}9.6 \\
18.6 \\
22.0 \\
49.8\end{array}$ \\
\hline $\begin{array}{l}\text { 7. Reason of my first visit to the dentist } \\
\text { 1. There was no dental pain. } \\
\text { 2. There was severe dental pain. } \\
\text { 3. There was little dental pain. } \\
\text { 4. I was feeling not comfortable. } \\
\text { 5. I felt nothing. } \\
\text { 6. There was enough time for treatment. }\end{array}$ & $\begin{array}{l}39 \\
35 \\
46 \\
39 \\
20 \\
36\end{array}$ & $\begin{array}{c}18.1 \\
16.4 \\
21.2 \\
18.4 \\
9.1 \\
16.8\end{array}$ \\
\hline $\begin{array}{l}\text { 8.If you do not visit the dentist or are afraid of him } \\
\text { or her, the reason(s) is (are): } \\
\text { 1. I am afraid of the dental needle } \\
\text { 2. There are no dental clinics in jail. } \\
\text { 3. There is no time. } \\
\text { 4. There is no pain to go to dentist. }\end{array}$ & $\begin{array}{c}46 \\
140 \\
21 \\
148\end{array}$ & $\begin{array}{c}12.9 \\
39.3 \\
5.9 \\
41.9\end{array}$ \\
\hline
\end{tabular}

\section{Discussion}

The present study was undertaken to assess the oral health knowledge, attitude and practice among the prison inmates of the Ambala district, Haryana. A total of 570 subjected were enrolled in the study.

The mean age of the study population in our study was found to be 35.26 years with minimum subject age was 18 years while the maximum was 88 years which is similar to other studies done by Dhanker $\mathrm{K}$ et al. (2013) [1], Heidari E et al. (2007) [2] and Osborn M et al. (2007) [5]. Male to female ratio (10.08:1) was similar to other studies Heng CK (2002) [6], Mack F (2004) [7] and Avon SL (2016) [9]. While most studies were conducted only on male prisoners $[8,9]$, only one study was found to be conducted exclusively on female inmates [6].
Table 4. Distribution of Practice score among prison inmates regarding oral health.

\begin{tabular}{|l|c|c|}
\hline & Frequency & Percent (\%) \\
\hline 1. How often do you brush your teeth? & 58 & 10.2 \\
1. Less than once per day. & 333 & 58.5 \\
2. Once per day. & 162 & 28.4 \\
3. Twice per day. & 17 & 2.9 \\
\hline 4. More than twice per day. & & \\
\hline 2. What do you use for cleaning your teeth? & 513 & 90.0 \\
1. Brush + toothpaste. & 31 & 5.6 \\
2. Datun & 16 & 2.8 \\
3. Finger. & 5 & .9 \\
4. Charcoal. & 5 & .9 \\
\hline 5. Others (specify)........... & & \\
\hline 3. When do you brush your teeth? & 451 & 79.2 \\
1. Morning. & 14 & 2.4 \\
2. Noon (after lunch). & 10 & 1.7 \\
3. Before going to bed. & 58 & 6.2 \\
\hline 4.Morning and evening & 37 & \\
\hline 5. Other times (specify)...... & & 7.1 \\
\hline 4. For how long do you brush your teeth? & 40 & 7.5 \\
\hline 1. Less than one minute. & 43 & 25.7 \\
2. One minute. & 146 & 59.7 \\
\hline 3. Two minutes. & 340 & 59.4 \\
4. More than two minutes. & 339 & 40.6 \\
\hline 5. Are you in habit of tobacco use? & 231 & 14.0 \\
\hline a) yes & & \\
b) no & 34 & \\
\hline 6. Which form of tobacco? & & \\
a)smoking & & \\
b)chewing & & \\
c)both & & \\
\hline
\end{tabular}

The Education level varied amongst the prisoners with higher number of subjects (26\%) being illiterate followed by $20.6 \%$ with high school education. Total subjects having a graduation degree was only $10 \%$. The level of education of the study subjects was similar to study reported by Dhanker Ket al. (2013) [1], Nobile CGA (2007) [10], where around $35 \%$ of the study subjects had no or only elementary education. Subjects holding a degree were $9.95 \%$, which was lower than Nobile CGA (2007) [10]. High percentage of subjects with less education in prison could be because such people will have less opportunity for jobs and resort to illegal activities and land up in jail. The overall literacy rate was similar to the study reported by Sajid A et al. (2006) [11]. A high number of inmates (30.05) were falling in the category of clerical, shopkeeper and former followed by semiprofessional and least was the unskilled which is similar to another study done by Salive ME et al. (1989) [12]. The reason for being maximum subjects in the category of farmer and clerk is that, they might have less education and have less opportunity to get good job placements.

In the present study the knowledge about the oral health is found to be poor as only $47 \%$ of the subjects know about the dental caries and $51 \%$ of the subjects did not know how to protect from gum disease which is accordance with Cheah WL (2009) [14] but lesser than the study done by the Humagain M (2011) [13] and Al Omiri et al. (2005) [15]. Only $8.3 \%$ of the subjects know about dental plaque which is not accordance with other study done by Arlappa N et al. (2011) [16] on general population showing the lesser level of knowledge among the prisoners about oral health. Although $86.81 \%$ of subjects believe that smoking is injurious to health and $72.05 \%$ subjects knew that it could cause cancer. This may be attributed to the warning sign over the tobacco products.

In our study attitude of prison inmates shows that $45 \%$ of the 
subjects believe, it is necessary to visit to dentist for better oral health which is accordance with study done by Humagain M (2011) [13] but contrary to it, $62.24 \%$ of subjects had never visited the dentist even before imprisonment which is lesser than the study done by Dhanker $\mathrm{K}$ et al. (2013) [1], and Peterson PE (2005) [18] showing negative attitude. The reason might me restricted freedom of movement in the prison, which is main barrier to access to oral health care services

In the present study, $38 \%$ of the population had past dental visit which is in accordance with other studies conducted by Nobile CGA et al. (2007) [11] and Osborn $\mathrm{M}$ et al. (2003) [5]. Out of total population, most common reason for a visit is dental pain which is in accordance with a study conducted by Heidari E (2007) [2], Cheah WL (2009) [14] in general population and $27.44 \%$ of subjects had tooth extraction in the last visit. This may be due to the fact that prisoner with low knowledge of oral health and they seek treatment only in dental emergencies.

However, most of the subjects $90.0 \%$ use toothbrush and toothpaste as a cleaning aid which is similar which is similar to the other studies done by Jones CM et al. (2002) [19] and Heidari E et al. (2007) [2]. Out of the total population $58 \%$ of the subjects brush their teeth once a day. Although more than half of the study subjects used to smoke tobacco, it was found to be lesser than that found in other studies Cropsey KL et al. (2007) [20], Nobile CGA et al. (2006) [10]. Along with smoking tobacco, quite of a large number of subjects were habitual of chewing tobacco. Hence, the overall use of tobacco was found to be similar to Cropsey KL et al. (2007) [20].

\section{Conclusion}

Prisons are no more the detention or punishment centers. They are the centers for correction of social behavior. Hence, the prisoners' health becomes the total responsibility of the state government. Total medical and dental examination, should be made mandatory for people before admission to the prisons to prevent further complications and to treat the existing conditions. Oral health education should be imparted to the prisoner time to time and De-addiction clinics or programs should be established in the prisons.

\section{References}

1. Dhanker K, Ingle N A, Kaur N, Gupta R (2013) Oral Health Status and Treatment Needs of Inmates in District Jail of Mathura City - A Cross Sectional Study. J Oral Health Comm Dent 7: 24-32.

2. Heidari E, Dickinson C, Wilson R, Fiske J (2007) Verifiable CPD paper: oral health of remand prisoners in HMP Brixton, London. Br Dent J 202: E1. [Crossref]
3. Singh S K, Sabyasachi S, Jagannath G V, Singh P (2012) Nature of Crime, Duration of Stay, Parafunctional Habits and Periodontal Status in Prisoners. J Oral Health Comm Dent 6: 31-134.

4. Berkman A (1995) Prison health: the breaking point. Am J Public Health 85: 16161618. [Crossref]

5. Osborn M, Butler T, Barnard PD (2003) Oral health status of prison inmates--New South Wales, Australia. Aust Dent J 48: 34-38. [Crossref]

6. Heng CK, Morse DE (2002) Dental caries experience of female inmates. J Public Health Dent 62: 57-61. [Crossref]

7. Mack F, Mojon P, Budtz-Jørgensen E, Kocher T, Splieth C, et al. (2004) Caries and periodontal disease of the elderly in Pomerania, Germany: results of the Study of Health in Pomerania. Gerodontology 21: 27-36. [Crossref]

8. Wyatt CC (2002) Elderly Canadians residing in long-term care hospitals: Part II. Dental caries status. J Can Dent Assoc 68: 359-363. [Crossref]

9. Avon SL (2004) Oral mucosal lesions associated with use of quid. J Can Dent Assoc 70: 244-248. [Crossref]

10. Nobile CG, Fortunato L, Pavia M, Angelillo IF (2007) Oral health status of male prisoners in Italy. Int Dent $J$ 57: 27-35. [Crossref]

11. Sajid A, Nalini S, Elizabeth D (2006) Prevalence and socio-demographic factors associated with tobacco smoking among adult males in rural Sindh, Pakistan. Southeast Asian J Trop Med Public Health 37: 1054-1060. [Crossref]

12. Salive ME, Carolla JM, Brewer TF (1989) Dental health of male inmates in a state prison system. J Public Health Dent 49: 83-86. [Crossref]

13. Humagain M (2011) Evaluation of Knowledge, Attitude and Practice (KAP) About Oral Health Among Secondary Level Students of Rural Nepal - A Questionnaire Study. Webmed Central dentistry 2: wmc001805.

14. Cheah WL, Tay SP, Chai SC, Bong CS, Luqmanul HB, et al. (2010) Oral health knowledge, attitude and practice among secondary school students in Kuching, Sarawak. Archives of Orofacial Sciences 5: 9-169.

15. Al-Omiri MK, Al-Wahadni AM, Saeed KN (2006) Oral health attitudes, knowledge, and behavior among school children in North Jordan. J Dent Educ 70: 179-187. [Crossref]

16. Arlappa N, Aatif Qureshi I, Srinivas R (2013) Fluorosis in India: an overview. Int J Res Dev Health 1:2.

17. Zhu L, Peterson PE, Wang HY, Bian JY, Zhang BX. Oral health knowledge, attitudes and behavior in China. Int $J$ Dent.

18. Petersen PE, Bourgeois D, Ogawa H, Estupinan-Day S, Ndiaye C (2005) The global burden of oral diseases and risks to oral health. Bull World Health Organ 83: 661-669. [Crossref]

19. Jones C M, McCann M, Nugent Z (2004) Scottish prisons' dental health survey2002. Scottish executive, Edinburgh.

20. Cropsey KL, Crews KM, Silberman SL (2006) Relationship between smoking status and oral health in a prison population. $J$ Correctional Health Care 12: 240-224.

Copyright: (C2015 Digra R. This is an open-access article distributed under the terms of the Creative Commons Attribution License, which permits unrestricted use, distribution, and reproduction in any medium, provided the original author and source are credited. 